\title{
Sciendo
}

\section{Serum malondialdehyde (MDA) level as a potential biomarker of cancer progression for patients with bladder cancer}

\author{
ZAHID LEPARA ${ }^{1}$, ORHAN LEPARA ${ }^{2}$, ALMIR FAJKIĆ ${ }^{3}$, DAMIR REBIĆ ${ }^{4}$, JASMIN ALIĆ ${ }^{1}$, HAJRUDIN SPAHOVIĆ \\ ${ }^{1}$ Urology Clinic, Clinical Center University of Sarajevo, Bolnička 25, 71000 Sarajevo, Bosnia and Herzegovina \\ ${ }^{2}$ Department of Physiology, Faculty of Medicine, University of Sarajevo, Čekaluša 90, 71000 Sarajevo, Bosnia and Herzegovina \\ ${ }^{3}$ Department of Pathophysiology, Faculty of Medicine, University of Sarajevo, Čekaluša 90, 71000 Sarajevo, Bosnia and Herzegovina \\ ${ }^{4}$ Nephrology Clinic, Clinical Center University of Sarajevo, Bolnička 25, 71000 Sarajevo, Bosnia and Herzegovina
}

\begin{abstract}
Introduction. Bladder cancer is the most common malignancy involving the urinary system. Recent research tends to emphasize the role of oxidative stress products in the carcinogenesis of bladder cancer. The level of oxidative stress can be measured by assessing the MDA levels. This study aimed to evaluate serum MDA levels in patients with bladder cancer, as well as to determine its potential role as a biomarker in the diagnosis of the disease and progression risk considerations.

Methods. The study was designed as a cross-sectional study and included 90 patients, divided into three groups with 30 patients each: Ta, T1 and T2-T4 group, based on histopathological findings after transurethral resection of the tumor. The control group included 30 healthy volunteers. MDA level was determined using the spectrophotometric method.

Results. Serum MDA level in patients with bladder cancer $[0.86(0.78-1.05) \mu \mathrm{mol} / \mathrm{L}]$ was significantly higher than the serum MDA level in control group $[0.70(0.69-0.72) \mu \mathrm{mol} / \mathrm{L}](\mathrm{p}<0.001)$. Serum MDA level in Ta group $[0.73(0.70-1.05) \mu \mathrm{mol} / \mathrm{L}]$, T1 group $[0.85(0.80-1.12) \mu \mathrm{mol} / \mathrm{L}]$ and in T2-T4 group [0.91 $(0.84-1.04) \mu \mathrm{mol} / \mathrm{L}]$ was significantly higher than the serum MDA level in control group [0.70 $(0.69-0.72) \mu \mathrm{mol} / \mathrm{L}](\mathrm{p}<0.01)$. MDA level in $\mathrm{T} 1$ and $\mathrm{T} 2-\mathrm{T} 4$ group was significantly higher than the MDA level in Ta group $(\mathrm{p}<0.01)$. No significant difference was observed in MDA level between T1 and T2-T4 group ( $\mathrm{p}=\mathrm{NS})$. A statistically significant positive correlation was found between tumor size and serum MDA level in patients with bladder cancer (rho $=0.254 \mathrm{p}<0.01$ ).

Conclusions. The results of the present study suggest that MDA serum level might play a significant role as a biomarker in the diagnosis of bladder cancer, as well as in the monitoring of its progression.
\end{abstract}

Key words: bladder cancer, biomarker, oxidative stress, cancer progression, malondialdehyde.

\section{INTRODUCTION}

Bladder cancer is the most common malignancy involving the urinary system, with 430,000 new cases diagnosed in 2012 [1,2].

The risk of bladder cancer shows geographical variation, correlating with smoking habits and occupational exposures to carcinogens in developed countries, and with chronic bladder infections in Africa and the Middle East [3].

Approximately $70-75 \%$ of bladder cancers are non-muscle invasive (NMIBC). NMIBC is defined as neoplasia confined to the mucosa (including $\mathrm{Ta}$ and carcinoma in situ (CIS)) or lamina propria (T1), based on tumor node metastases (TNM) classification. Ta accounts for most NMIBC (60\%), whereas T1 and Tis (CIS) account for $30 \%$ and $10 \%$, respectively $[3,4]$. Muscle invasive blader cancer (MIBC) includes muscle layer invasive forms (T2) and higher stage cancers which invade beyond the muscle layer into perivesical tissue (T3) or surrounding organs (T4).
Recent research tends to emphasize the role of oxidative stress products in carcinogenesis as well as the role of antioxidants in the prevention and treatment of bladder cancer $[5,6]$. Oxidative stress is defined as the excessive production of reactive oxygenated/nitrogenated species (ROS/RNS) that cannot be balanced by the action of antioxidants. Lipid peroxidation (LPO) is a complex process of oxidative degradation which produces malondialdehyde (MDA), 4-hydroxynonenal (4-HNE), and isoprostanes from polyunsaturated fatty acids (PUFAs). Unstable free radicals take electrons from lipids promoting chain reaction that results in lipid instability and formation of these by-products. They initiate the structural modifications and function modulation in nucleic acids, lipids, and proteins and act both mutagenic and carcinogenic [7-10].

Many studies are examining the LPO and antioxidant enzyme activities in cancerous bladder tissue, which suggest that oxidative stress plays a crucial role in the carcinogenesis of bladder cancer 
[5, 11-19]. LPO in biological membranes has structural and dynamical effects, such as an increase of permeability, a decrease of the bilayer thickness, or modifications in the lipid membrane order and fluidity [20]. Moreover, MDA from the lipid peroxidation process reacts with cellular nucleophiles such as glutathione and cysteine, histidine, lysine residues of the protein, which causes destructive functional modification and its effect on DNA resulting in a genotoxic effect that promotes bladder cancer [21]. Bladder cancer is a disease of old age, and the accumulation of oxidative stress may be a potential risk factor for the process of carcinogenesis in those patients.

The level of oxidative stress and LPO can be measured by assessing the MDA levels. This study aimed to evaluate serum MDA levels in patients with bladder cancer, as well as to determine its potential role as a biomarker in the diagnosis of the disease and progression risk considerations.

\section{MATERIALS AND METHODS}

\section{Patients}

The study was designed as a cross-sectional study and included 90 patients, both genders with confirmed bladder cancer. Based on pathological findings, the patients were divided into three groups with 30 patients each: non-invasive, superficial bladder cancer groups ( $\mathrm{Ta}$ and $\mathrm{T} 1$ ), and invasive bladder cancer group (T2-T4). The control group included 30 healthy volunteers, without the manifested urological disease, who were age and gender-matched to bladder carcinoma groups. Due to the potential impact of inflammatory conditions, patients and control subjects with acute or chronic inflammatory diseases, asthma, liver cirrhosis, Crohn's disease and ulcerative colitis, pituitary tumors, multiple sclerosis, or other malignant neoplasia were excluded from the study. All samples were collected after obtaining informed consent from all individuals, and the study was approved by the Clinical Center University of Sarajevo Ethics Committee.

\section{Methods}

After carrying out diagnostic procedures, which included physical examination, urological examination, ultrasonography (US) of the bladder, intravenous urography (IVU), urethrocystoscopy, a definite indication for surgery (transurethral resection - TUR) was given. After histopathological analysis, the definitive selection of patients was performed. The grade and stage of tumors were determined according to the TNM (Tumor Nodules Metastases) classification of malignant tumours based on histopathological examination. Patients were also divided into groups by cancer grade, which is defined as low-grade and high-grade after histopathological analysis, according to cancer progression potential.

\section{Measurement of MDA}

Due to the possible influence of surgery and diagnostic procedures on the serum MDA level, blood sampling was performed before any procedures during the first examination of the patients at the Urology Clinic, Clinical Center University of Sarajevo. The blood sample was collected during the routine biochemical tests that are part of the diagnostic protocol.

After spontaneous precipitation of the blood sample for 20 minutes, it was centrifuged for 5 minutes at 3,000 rpm, and then for 15 minutes more at $10,000 \mathrm{rpm}$ and $0.2 \mathrm{~mL}$ of serum was extracted for MDA analysis. The serum was stored at $-80^{\circ} \mathrm{C}$ until analysis.

MDA level was determined using the spectrophotometric method (Spectrophotometer UV/Vis, Perkin Elmer, Lambda 25).

\section{Statistical analysis}

Data was provided as a median and interquartile range, and Shapiro-Wilk test was used for the data distribution analysis. Depending on the distribution of variables, a comparasion between the groups was performed by the ANOVA test and Kruskal-Walls or Mann-Whitney U Test. Additionally, since variables were not normally distributed, correlations were assessed by Spearman's test. To determine optimal cut-off values of MDA for differentiation between bladder cancer and control group (CG), as well as for differentiation of patients with low grades and high grades, receiver operating characteristic (ROC) curves and their corresponding areas under the curve (AUC) were used. The accuracy rate for ROC curves was calculated with a $95 \%$ confidence interval $(95 \% \mathrm{CI})$. P values $<0.05$ were considered statistically significant. Statistical analyses were performed using IBM SPSS 23.0 statistical software system (IBM Corporation, Chicago, Illinois). 


\section{RESULTS}

The baseline characteristics of the three study groups are shown in Table 1. In terms of gender distribution, men were dominant in all groups [53.3\% vs. $46.7 \%$ (control group), $73.7 \%$ vs. $26.7 \%$ (Ta group), $76.6 \%$ vs. $23.4 \%$ (T1 group), $66.6 \%$ vs. $33.4 \%$ (T2-T4 goup)]. In terms of distribution of patient by habit of tobacco consumption, smokers were dominant in all groups [ $43.3 \%$ vs. $57.3 \%$ (control group), $86.6 \%$ vs. $13.4 \%$ (T1 group), $70.0 \%$ vs. $30.0 \%$ (Ta group), $83.4 \%$ vs. $16.6 \%$ (T2-T4 goup)]. This difference was statistically significant $\left(\chi^{2}=16.901\right.$, $\mathrm{p}=0.001)$.

Tumor size was $1.0(0.5-1.5) \mathrm{cm}, 1.75$ $(1.0-2.0) \mathrm{cm}, 3(3.0-4.0) \mathrm{cm}$, in Ta, T1 and T2-T4 goup, respectively. A high-grade tumor was found in patients in $\mathrm{T} 2-\mathrm{T} 4(100 \%)$ and $\mathrm{T} 1$ groups $(46.6 \%)$, while low-grade tumor was discovered in patients in Ta (100\%), and T1 group (54.4\%).

Serum MDA level in patients with bladder cancer $[0.86(0.78-1.05) \mu \mathrm{mol} / \mathrm{L}]$ was significantly higher than the serum MDA level in control group [0.70 (0.69-0.72) $\mu \mathrm{mol} / \mathrm{L}](\mathrm{p}<0.001)$.

Serum MDA level in Ta group [0.73 (0.70-1.05) $\mu \mathrm{mol} / \mathrm{L}]$, T1 group $[0.85(0.80-1.12) \mu \mathrm{mol} / \mathrm{L}]$ and in T2-T4 group [0.91 $(0.84-1.04) \mu \mathrm{mol} / \mathrm{L}]$ was significantly higher than the serum MDA level in control group $[0.70(0.69-0.72) \mu \mathrm{mol} / \mathrm{L}](\mathrm{p}<0.01)$. MDA level in T1 and T2-T4 group was significantly higher than the MDA level in Ta group $(\mathrm{p}<0.01)$. No significant difference was observed in MDA level between $\mathrm{T} 1$ and $\mathrm{T} 2-\mathrm{T} 4$ group $(\mathrm{p}=\mathrm{NS})$ [Figure 1].

Table 1

Baseline characteristics of patients with bladder cancer and control group

\begin{tabular}{|c|c|c|c|c|c|c|}
\hline \multicolumn{2}{|c|}{ Variables } & $\begin{array}{c}\text { CG } \\
(n=30)\end{array}$ & $\begin{array}{c}\text { Ta group } \\
(\mathbf{n}=\mathbf{3 0})\end{array}$ & $\begin{array}{c}\text { T1 group } \\
(\mathbf{n}=\mathbf{3 0})\end{array}$ & $\begin{array}{c}\text { T2-T4 group } \\
(n=30)\end{array}$ & $\mathbf{P}$ \\
\hline \multicolumn{2}{|l|}{ Age } & $66.86 \pm 3.67$ & $69.0 \pm 7.76$ & $68.56 \pm 8.86$ & $68.9 \pm 10.48$ & 0.830 \\
\hline \multicolumn{2}{|c|}{$\begin{array}{l}\text { Gender } \\
\text { (male/female) }\end{array}$} & $16(53.3 \%) / 14(46.7 \%)$ & $22(73.7 \%) / 8(26.7 \%)$ & $23(76.6 \%) / 7(23.4 \%)$ & $20(66.6 \%) / 10(33.4 \%)$ & 0.224 \\
\hline \multicolumn{2}{|c|}{ Tumor size $(\mathrm{cm})$} & - & $1.0(0.5-1.5)$ & $1.75(1.0-2.0)$ & $3(3.0-4.0)$ & $<0.001$ \\
\hline \multicolumn{2}{|l|}{ Smoking } & $13(43.3 \%)$ & $21(70.0 \%)$ & $26(86.6 \%)$ & $25(83.4 \%)$ & 0.001 \\
\hline \multicolumn{2}{|l|}{ Drinking } & $16(53.3 \%)$ & $18(60.0 \%)$ & $22(73.3 \%)$ & $22(73.3 \%)$ & 0.266 \\
\hline \multirow{2}{*}{$\begin{array}{l}\text { Tumor } \\
\text { grades }\end{array}$} & high & - & - & $14(46.6 \%)$ & $30(100 \%)$ & \\
\hline & low & - & $30(100 \%)$ & $16(54.4 \%)$ & - & \\
\hline
\end{tabular}

CG - control group, Ta, T1 group - patients with superficial, non-invasive bladder cancer, T2-T4 group - patients with invasive bladder cancer. Data are presented as median and $\min / \max$ values.

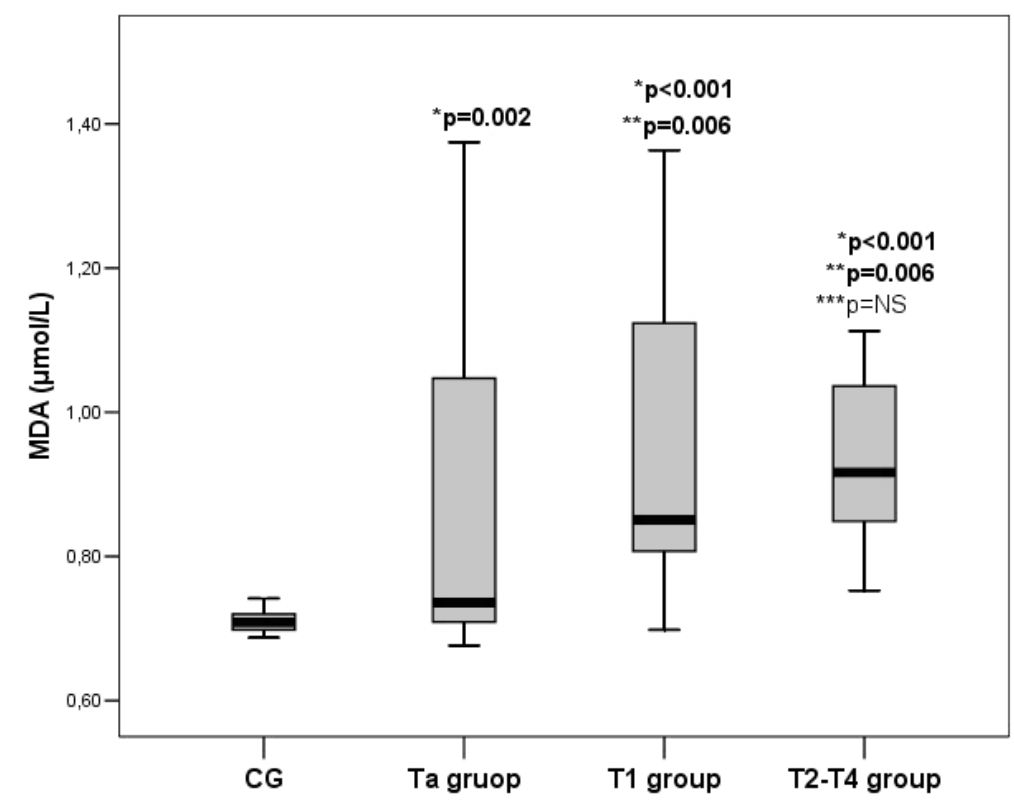

Figure 1. Serum level MDA in patients with different stages of bladder carcinoma and control group. CG - control group, Ta group - patients with non-invasive, superficial bladder cancer, T1 group - patients with superficial bladder cancer, T2-T4 group - patients with invasive bladder cancer, ${ }^{*} \mathrm{p}$ - in comparison to the $\mathrm{CG},{ }^{* *} \mathrm{p}-$ in comparison to the Ta group; $* * * \mathrm{p}$ - in comparison to the T1 group; NS - not significant. 
Serum MDA level in patients with bladder cancer with high grade $[0.90(0.82-1.05) \mu \mathrm{mol} / \mathrm{L}]$ was significantly higher than the serum MDA level in patients with bladder cancer with low grade [0.81 $(0.72-1.05) \mu \mathrm{mol} / \mathrm{L}](\mathrm{p}=0.006)$ [Figure 2] .

The optimal cut-off value of MDA determined by the ROC curve in differentiating patients with bladder cancer vs. control group was $\geq 0.769 \mu \mathrm{mol} / \mathrm{L}$. AUC for determined cut-off value was 0.899 with $95 \%$ CI of $0.845-0.953(\mathrm{p}<0.001)$. For a calculated optimal MDA cut-off value of $\geq 0.769 \mu \mathrm{mol} / \mathrm{L}$, the specificity was $76.7 \%(95 \% \mathrm{CI}, 66.4-84.7)$, and sensitivity was $100 \%(95 \% \mathrm{CI}, 85.8-100)$ [Table 2].
The optimal cut-off value of MDA determined by the ROC curve in differentiating patients with LG vs. HG was $\geq 0.790 \mu \mathrm{mol} / \mathrm{L}$. AUC for determined cut-off value was 0.667 with $95 \%$ CI of $0.549-0.784$ $(p=0.006)$. For a calculated optimal MDA cut-off value of $\geq 0.790 \mu \mathrm{mol} / \mathrm{L}$, thespecificity was $91.1 \%$ (95\% CI, 77.9-97.2), andsensitivity was $48.8 \%$ (95\% CI, 33.9-64.0) [Table 3].

A statistically significant positive correlation was found between tumor size and serum MDA level in patients with bladder cancer ( $r h o=0.254 \mathrm{p}<0.01$ ). However, no statistically significant correlation was observed between MDA level and tumor size in individual patient groups (Ta group, $\mathrm{T} 1$ group, and $\mathrm{T} 2-\mathrm{T} 4$ group) (data not shown).

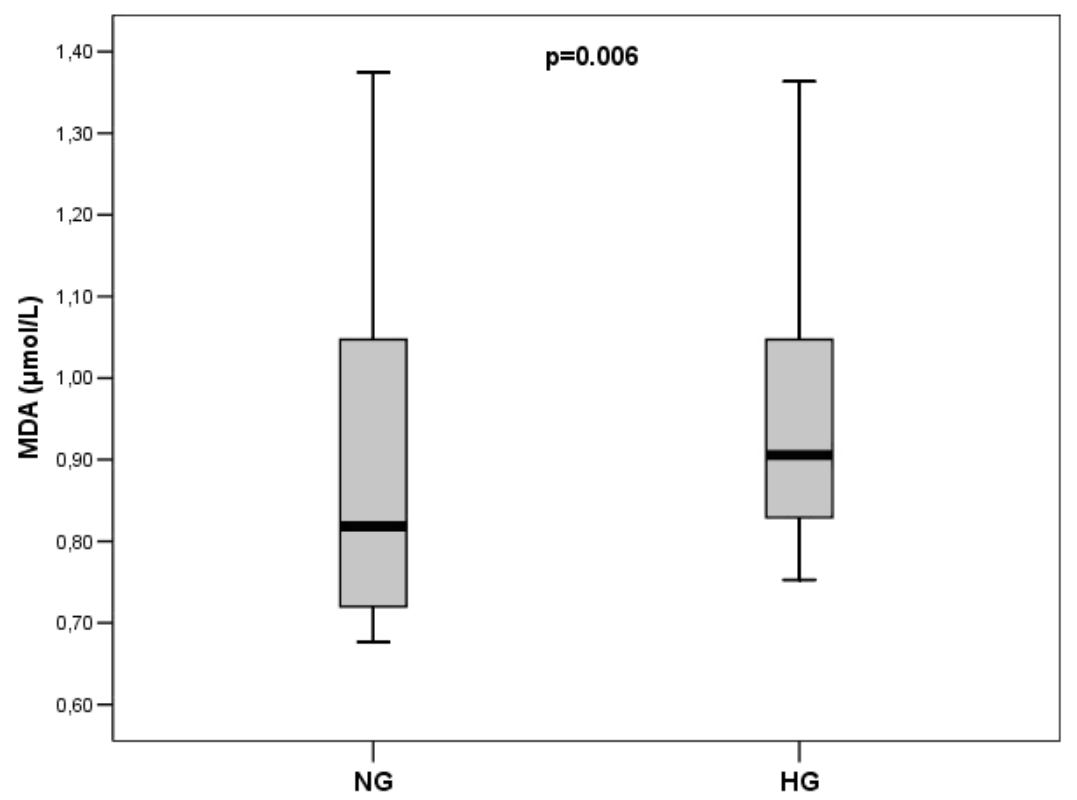

Figure 2. Serum level MDA in patients with different grades of bladder carcinoma. LG - low grade, HG - high grade.

Table 2

Optimal cut-off, area under the curve (AUC) with 95\% confidence interval (95\% CI), sensitivity, specificity, the positive and negative predictive value of serum MDA in differentiating between patients with bladder cancer and healthy controls

\begin{tabular}{|c|c|c|c|c|c|c|c|}
\hline & $\begin{array}{c}\text { Optimal } \\
\text { Cut off }\end{array}$ & $\begin{array}{c}\text { AUC } \\
(\mathbf{9 5 \%} \text { CI) }\end{array}$ & $\begin{array}{c}\text { Sensitivity } \\
\mathbf{( \% )}\end{array}$ & $\begin{array}{c}\text { Specificity } \\
\mathbf{( \% )}\end{array}$ & $\begin{array}{c}\text { Positive } \\
\text { predictive } \\
\text { value (\%) }\end{array}$ & $\begin{array}{c}\text { Negative } \\
\text { predictive value } \\
(\%)\end{array}$ & p $<$ \\
\hline $\mathrm{BC} v s . \mathrm{CG}$ & $(\geq 0.769 \mu \mathrm{mol} / \mathrm{L})$ & $\begin{array}{c}0.899 \\
(0.845-0.953)\end{array}$ & $\begin{array}{c}76.6 \\
(66.4-84.7)\end{array}$ & $\begin{array}{c}100.0 \\
(85.8-100)\end{array}$ & $\begin{array}{c}100.0 \\
(79.3-100)\end{array}$ & $\begin{array}{c}69.6 \\
(59.5-78.3)\end{array}$ & 0.001 \\
\hline
\end{tabular}

$\mathrm{BC}$ - patients with bladder cancer, $\mathrm{CG}-$ control group

Table 3

Optimal cut-off, area under the curve (AUC) with 95\% confidence interval ( $95 \% \mathrm{CI})$, sensitivity, specificity, the positive and negative predictive value of serum MDA in differentiating between patients with low and high grade

\begin{tabular}{|c|c|c|c|c|c|c|c|}
\hline & $\begin{array}{c}\text { Optimal } \\
\text { Cut off }\end{array}$ & $\begin{array}{c}\text { AUC } \\
\mathbf{( 9 5 \%} \text { CI) }\end{array}$ & $\begin{array}{c}\text { Sensitivity } \\
\mathbf{( \% )}\end{array}$ & $\begin{array}{c}\text { Specificity } \\
\mathbf{( \% )}\end{array}$ & $\begin{array}{c}\text { Positive } \\
\text { predictive } \\
\text { value (\%) }\end{array}$ & $\begin{array}{c}\text { Negative } \\
\text { predictive value } \\
\mathbf{( \% )}\end{array}$ & p= \\
\hline LG vs. HG & $(\geq 0.790 \mu \mathrm{mol} / \mathrm{L})$ & $\begin{array}{c}0.667 \\
(0.549-0.784)\end{array}$ & $\begin{array}{c}91.1 \\
(77.9-97.2)\end{array}$ & $\begin{array}{c}48.8 \\
(33.9-64.0)\end{array}$ & $\begin{array}{c}85.1 \\
(65.3-95.1)\end{array}$ & $\begin{array}{c}65.0 \\
(51.9-76.3)\end{array}$ & 0.006 \\
\hline
\end{tabular}

LG - low grade, HG - high grade 


\section{DISCUSSION}

Recent research has shown that free radicals and oxidative processes are involved in the onset and development of some malignancies. According to the oxidative hypothesis of carcinogenesis, many carcinogens can generate free radicals that cause not only cell damage but also create conditions for malignant transformation of these cells. Oxidative stress via lipid peroxidation products, such as MDA, plays a significant role in the pathogenesis of a large number of malignancies, including lung, colon, kidney, bladder, etc. [11].

MDA is one of the best-investigated products of lipid peroxidation. It is presumed that MDA acts as a tumor promoter and a co-carcinogenic agent because of its high cytotoxicity and inhibitory action on antioxidant enzymes [22]. The MDA serum level reflects free-radical cell damage. The results of our study showed that the MDA serum level in Ta, T1, and T2-T4 group was significantly higher than the MDA level in the control group, a finding compatible with the results of several studies [12-19]. The MDA levels of the patients in $\mathrm{T} 1$ and T2-T4 groups were significantly higher than in the Ta group, whereas the MDA serum levels between the T1 and T2-T4 groups were not statistically significant.

Honglertsakul et al. have shown that the urine MDA level was statistically significantly higher in patients with a higher grade, as well as in the control group of subjects. Their results suggest that reducing oxidative stress could open up a new approach in preventing the progression of this disease [12]. Badrinath et al. found significantly higher levels of MDA in the urine of patients with bladder cancer compared to the healthy control subjects [13].

Our research implicates a correlation between tumor size and serum MDA level. According to our observations, it is difficult to conclude on the effect of tumor size on the MDA level or vice versa. There is the possibility that higher serum MDA levels may reflect tumor growth and progression. Also, contribution of higher serum MDA levels in promotion of tumor growth is not excluded. In the available literature, we did not find a study that examined the association between tumor size and serum MDA level.

ROC curve analysis suggested that serum MDA levels could serve as a potential biomarker in the differentiation of cancer grade, as well as cancer progression potential. A recent study performed by Sawicka et al. showed that serum MDA level had the highest growth in the G3 group compared with controls, and among Ta, T1, and T2, the MDA level increased against the control by a similar percentage [17]. Unlike this, Yalcin et al. reported the growth of MDA concentrations among G1 and G2 patients [14]. Our results showed that the serum MDA level of patients with bladder cancer could have a potential role in differentiating the low and highly progressive types of this cancer, where the sensitivity was $98.3 \%$, specificity $53.3 \%$, as well as in differentiating the cancer grade, where the sensitivity was $86.7 \%$, specificity $60.0 \%$.

It was suggested that with the advancing stage of bladder cancer, the levels of oxidative stress increase, while levels of antioxidant molecules decrease. Badjatia et al. found significant correlations between these changes with the grade and stage of the disease. They even suggest the possible use of antioxidant supplementation as prophylactic agents for the prevention and treatment of bladder cancer [23].

MDA could be utilized as a biomarker after excluding the inflammatory conditions, cardiovascular, metabolic, and liver disease, which have an impact on the MDA levels. A study performed by El Gendy et al. included patients with invasive bladder carcinoma infected with bilharziasis, patients with bilharziasis but no tumor, and a healthy control group. A significant increase in MDA was observed in $63 \%$ of patients with bladder cancer. After stratification of patients according to grade and stage, no statistically significant difference in MDA level was observed [14].

Kaczmarek et al. compared serum MDA level before and after treatment with the intravesical bacillus Calmette-Guerin (BCG) Mycobacterium suspension in patients previously treated with transurethral resection of bladder tumor. The platelet MDA level after BCG treatment decreased significantly and sustained this decline for a month. They suggested that the use of adjuvant BCG therapy inhibits lipid peroxidation and, along with the increase of superoxide dismutase- 1 activity, results in a reduced aggregation of platelets, thus preventing the disease progression and metastasis [16].

Significantly increased levels of MDA has also been reported in various types of malignancies like lung, breast, oral cavity, oropharyngeal, liver, gastric, colorectal, ovarian, cervix, renal, and prostate cancer [18]. Dillioglugil et al. showed a strong correlation between all known prognostic indicators of prostate cancer and MDA levels [24]. Furthermore, MDA levels are increased in some other urological conditions, like benign prostate hyperplasia [25].

Regarding renal and bladder cancer, El-Far et al. have found that serum MDA levels were 
significantly higher in both types of cancer, reflecting the increase in oxidative damage and lipid peroxidation, but with no correlation with a cancer stage [26].

Our results speak in favor of the hypothesis that an increase in the level of oxidative stress and lipid peroxidation is associated with the progression of bladder cancer. If serum MDA level in patients with bladder cancer increases by 0.1 , the likelihood of the cancer progression to higher stage increases by 1.91 times.

Taking all this into account, we believe that patients with risk of disease, as well as patients who are already ill, could benefit from serum MDA evaluation as an additional test to standard protocol.

\section{CONCLUSION}

Tumor progression toward a higher stage accompanied by a significant increase in MDA levels suggests a possible role of oxidative stress in the pathogenesis and progression of the illness. The results of the present study suggest that MDA serum level might play a significant role as a biomarker in the diagnosis of bladder cancer, as well as in the monitoring of its progression. However, further research involving studies with higher sample size is required to determine the accuracy and widespread applicability of MDA as a biomarker in patients with bladder cancer.

Introducere. Cancerul de vezică urinară este o neoplazie frecventă. Descoperirile recente indică stresul oxidativ drept promotor. Nivelul stresului oxidativ poate fi evaluat prin analiza nivelurilor MDA. Scopul studiului a fost de a evalua nivelurile serice ale MDA ca biomarker pentru diagnosticul şi prognosticul tumorilor vezicale.

Metode. A fost realizat un studiu transversal cu 90 de pacienți împărțiti în 3 grupuri a câte 30 de pacienți T1, T1 și T2-T4 bazat pe examenul histopatologic. Grupul martor a inclus 30 de martori. Nivelul MDA a fost evaluat prin metodă spectrofotometrică.

Rezultate. Nivelurile MDA cu cancer vezical a fost semnificativ mai mare decât martorii sănătoși $[0,86(0,78-1,05) \mu \mathrm{mol} / \mathrm{L}]$ versus $[0,70(0,69-0,72) \mu \mathrm{mol} / \mathrm{L}]$ $(p<0,001)$. Nivelurile serice ale MDA în grupul Ta $[0,73(0,70-1,05) \mu \mathrm{mol} / \mathrm{L}]$, T1 $[0,85(0,80-1,12) \mu \mathrm{mol} / \mathrm{L}]$ și T2-T4 [0,91 $(0,84-1,04) \mu \mathrm{mol} / \mathrm{L}]$ au fost semnificativ mai mari față de martorii sănătoși $[0,70(0,69-0,72) \mu \mathrm{mol} / L](p<0,01)$. Nivelurile MDA au fost mai mari la pacienții din grupurile T1 și T2-T4. S-a observat o corelație pozitivă între dimensiunea tumorilor și nivelul seric MDA (rho $=0.254 p<0.01)$.

Concluzii. Rezultatele sugerează faptul că nivelurile serice ale MDA joacă un rol semnificativ ca biomarker pentru diagnosticul și monitorizarea progresiei tumorilor vezicale.

Correspondence to: Jasmin Alić, M.D., Urology Clinic, Clinical Center University of Sarajevo, Bolnička 25, 71000 Sarajevo, Bosnia and Herzegovina

Tel. 0038761390200

Tel./Fax. 0038733297130

E-mail: jasmin.allic@gmail.com

Conflict of interest disclosure: The authors declare that there are not conflicts of interest.

\section{REFERENCES}

1. TORRE LA, BRAY F, SIEGEL RL, et al. Global cancer statistics, 2012. CA Cancer J Clin. 2015; 65:87.

2. SIEGEL RL, MILLER KD, JEMAL A. Cancer statistics, 2019. CA Cancer J Clin. 2019; 69:7.

3. FONTEYNE V., OST P., BELLMUNT J., DROZ JP., MONGIAT-ARTUS P., INMAN B., et al. Curative Treatment for Muscle Invasive Bladder Cancer in Elderly Patients: A Systematic Review. Eur Urol 2018; 73:40.

4. KASSOUF W., TRABOULSI SL., KULKARNI GS., BREAU RH., ZLOTTA A., FAIREY A., et al. CUA guidelines on the management of non-muscle invasive bladder cancer. Can Urol Assoc J. 2015; 9(9-10):E690-704.

5. VALKO M., IZAKOVIC M., MAZUR M., RHODES CJ., TELSER J. Role of oxygen radicals in DNA damage and cancer incidence. Mol Cell Biochem. 2004; 266:37-565. 
6. KONG Q., BEEL JA., LILLEHEI KO. A threshold concept for cancer therapy. Med Hypotheses. 2000; 5:529-535.

7. PISOSCHI AM., POP A. The role of antioxidants in the chemistry of oxidative stress: A review. Eur J Med Chem. 2015; 97:55-74.

8. GUERAUD F., ATALAY M., BRESGEN N., CIPAK A., ECKL PM., HUC L., JOUANIN I., SIEMS W., UCHIDA K. Chemistry and biochemistry of lipid peroxidation products. Free Radic Res. 2010; 44:1098-1124.

9. ESTERBAUER H., SCHAUR RJ., ZOLLNER H. Chemistry and biochemistry of 4-hydroxynonenal, malonaldehyde and related aldehydes. Free Radic Biol Med. 1991; 11:81-128.

10. FARMER EE., DAVOINE C. Reactive electrophile species. Curr Opin Plant Biol. 200; 10 (4): 380-6.

11. BARRERA G. Oxidative stress and lipid peroxidation products in cancer progression and therapy. ISRN Oncol. 2012; 2012:137289.

12. HONGLERTSAKUL C., OPANURAKS J., KITTIKOWIT W., BOONLA C., WUNSUWAN R., TOSUKHOWONG P. Increased urinary excretions of oxidative stress biomarkers and sialic acid associated with severity of bladder tumors. The THAI Journal of surgery. 2007; 28:133-137.

13. BADRINATH RK., ROBERT AG. Urine based markers of urological malignancy. J Urol. 2001; 165: 600.

14. EL GENDY SM., SALAM AIM., EL-WAHAB NA., HUSSEIN MK., GABRY MS., EL-AASER AA. Urinary telomerase activity, $C$-erbB2, malondialdehyde and nitric oxide as biological markers of bladder cancer. Turk J Biochem. 2006; 31(4); 164-168.

15. YALCIN O., KARATAS F., ERULAS FA., OZDEMIR E. The levels of glutathione peroxidaes, vitamin A, E, $C$ and lipid peroxidation in patients with transitional cell carcinoma of the bladder. Br J Uro Int. 2004; 93(6): 863-866.

16. KACZMAREK P., BUCZYNSKI A., NIEMIROWICZ J., GNITECKI W., KOCUR E., KARPINSKI J. Lipids peroxidation in platelets in patients with bladder cancer treated with Mycobacterium suspension. Pol Merkuriusz Lek. 2001; 11: 484-6.

17. SAWICKA E., KRATZ EM., SZYMAŃSKA B., GUZIK A., WESOŁOWSKI A., KOWAL P., et al. Preliminary study on selected markers of oxidative stress, inflammation and angiogenesis in patients with bladder cancer. Pathol Oncol Res. 2019. doi: 10.1007/s12253-019-00620-5.

18. JELIC MD., MANDIC AD., MARICIC SM., SRDJENOVIC BU. Oxidative stress and its role in cancer. J Can Res Ther [Epub ahead of print] [cited 2019 Nov 9].

19. GECIT I., ASLAN M., GUNES M., PIRINCCI N., ESEN R., DEMIR H., CEYLAN K. Serum prolidase activity, oxidative stres and nitric oxide levels in patients with bladder cancer. J Cancer Res Clin Oncol 2012; 138:739-743.

20. TAI WY., YANG YC., LIN HJ., HUANG CP., CHENG YL., CHEN MF., YEN HL., LIAU I. Interplay between structure and fluidity of model lipid membranes under oxidative attack. The Journal of Physical Chemistry B. 2010; 114 (47): 15642-15649.

21. NIMET V., RUCKEN T. Effect of stress induced lipid peroxidation on cell function. International cell biology. 2004; 28(7):517-521.

22. SEVEN A., CIVELEK S., INCI E., KORKUT N., BURÇAK G. Evaluation of oxidative stress parameters in blood of patients with laryngeal carcinoma. Clin Biochem J, 1999; 32(5): 69-73.

23. BADJATIA N., SATYAM A., SINGH P., SETH A., SHARMA A. Altered antioxidant status and lipid peroxidation in Indian patients with urothelial bladder carcinoma. Urol Oncol J. 2010; 28 (4): 360-7.

24. DILLIOGLUGIL MO., MEKIK H., MUEZZINOGLU B., OZKAN TA., DEMIR CG., DILLIOGLUGIL O., et al. Blood and tissue nitric oxide and malondialdehyde are prognostic indicators of localized prostate cancer. Int Urol Nephrol. 2012; 44:1691-6.

25. KOSOVA F., TEMELTAŞ G., ARI Z., LEKILI M. Possible relations between oxidative damage and apoptosis in benign prostate hyperplasia and prostate cancer patients. Tumour Biol. 2014; 35:4295-9.

26. EL-FAR M., ABOL-ENEIN H., ZAKARIA A., EL-GEDAMY M. Evaluation of nitric oxide and malondialdehyde levels in serum of Egyptian patients with bladder and renal tumors: Potential use as medicinal biomarkers. World J Pharm Pharm Sci. 2014; 3:87-101.

Received February $14^{\text {th }} 2020$ 